\title{
Online Teaching during COVID-19 Pandemic: Teachers' Experiences from a Chinese University
}

\author{
Samson Maekele Tsegay ${ }^{1}$, Muhammad Azeem Ashraf ${ }^{2, *}$, , Shahnaz Perveen ${ }^{3}$ and Mulugeta Zemuy Zegergish ${ }^{4}$ \\ 1 School of Education and Social Care, Anglia Ruskin University, Young Street, Cambridge CB1 1PT, UK; \\ samex221@gmail.com \\ 2 Educational Science Research Institute, Hunan University, Changsha 410082, China \\ 3 Department of Education, The Government Sadiq College Women University Bahawalpur, \\ Bahawalpur 63100, Punjab, Pakistan; drshahnaz@gscwu.edu.pk \\ 4 Department of Psychology and Educational Administration, Asmara College of Education, Asmara, Eritrea; \\ dbmuler2015@yahoo.com \\ * Correspondence: azeem@hnu.edu.cn
}

Citation: Tsegay, S.M.; Ashraf, M.A.; Perveen, S.; Zegergish, M.Z. Online Teaching during COVID-19 Pandemic: Teachers' Experiences from a Chinese University. Sustainability 2022, 14, 568. https:// doi.org/10.3390/su14010568 Academic Editor: Jordi Colomer Feliu

Received: 5 November 2021 Accepted: 24 December 2021 Published: 5 January 2022

Publisher's Note: MDPI stays neutral with regard to jurisdictional claims in published maps and institutional affiliations.

Copyright: (C) 2022 by the authors. Licensee MDPI, Basel, Switzerland. This article is an open access article distributed under the terms and conditions of the Creative Commons Attribution (CC BY) license (https:// creativecommons.org/licenses/by/ $4.0 /)$.

\begin{abstract}
This paper explores the experiences of Chinese university teachers during the COVID-19 pandemic, with a particular emphasis on the teaching and learning methods adopted and the benefits and challenges encountered in the process. It is based on semi-structured interviews with 13 Chinese university teachers selected through purposive sampling. The findings suggest that the COVID-19 pandemic forced the university and teachers to adopt online teaching and learning without necessary preparations. Most of the teachers had no adequate ICT and pedagogical training to engage in online teaching and learning. The teachers used the little knowledge they had to learn creating videos and managing online classes gradually. In addition to the flexibility benefits, online learning is expected to transform the teaching and learning process in China to become more interactive and student-centered, which would be a significant achievement for teachers who have been practicing traditional teaching methods. This research provides a better understanding of the benefits and challenges of online learning, which could be vital for future adjustments or educational reforms.
\end{abstract}

Keywords: sustainable education; online learning; COVID-19; higher education; China

\section{Introduction}

The COVID-19 pandemic has affected the world in the health sector and many other sectors such as education, business, and tourism. With the spread of the COVID-19 outbreak and the increased mortality around the world, many countries decided to close schools, colleges, and universities. The closing of educational institutions caused the interruption of students' learning, especially in countries where internet connections are not strong or students lack vital resources such as computers [1]. In contrast, teaching and learning processes transformed into online learning in countries with reliable information and communication technologies (ICT) [2].

For example, the development and integration of ICT into education have shown significant progress in China, to the level that some cities have gained full coverage [3]. In addition, many Chinese universities have been offering online courses, although research suggests that the proportion of students choosing this approach to education is low compared to face-to-face classes, and it is often targeted to adult vocational students [4]. Furthermore, research reveals that most Chinese students need proper ICT training and a conducive environment to learn online from home $[5,6]$. These challenges are expected to increase during COVID-19.

The increase of COVID-19 cases and the measures taken to control the spread of the pandemic limited the availability of ample and quiet space for students to study, which primarily affects students from low socio-economic status [1]. With lockdowns forcing most 
or all family members to stay at home, many students face difficulties finding a conducive environment to focus and learn from home [6]. Moreover, teachers need to design a new method of teaching and learning which might require additional ICT and pedagogical training $[7,8]$. This is a major challenge for many teachers who have been focusing on traditional teaching and learning [7,9]. Conversely, research indicates that teachers who had been accustomed to interactive technology could adapt to online teaching quickly [10]. In addition, teachers' perception and understanding of interactive learning theories and practices affect their view on applying different learning activities in the classroom [11].

Despite its vast educational reform and development, Chinese educational institutions are commonly focused on exam-oriented education and, thus, teaching approaches with a tradition of lecturing and limited student participation [9,12-14]. Many scholars argue that such teaching practices are connected to the cultural perception of teachers and the academic participation and performance of students [7,9,15-17]. Teachers who perceive that they are the providers of knowledge while students are the receivers tend to use teachercentered teaching, resulting in low student participation and collaborative learning [18]. This approach also hinders students from taking responsibility for their learning [19]. The recent study by Asharaf et al. (2021) also showed that the efforts to adopt blended learning in Chinese schools would be challenging due to teachers' perceptions and pedagogical knowledge, and the exam-oriented nature of the Chinese education system. This suggests that the transformation of the Chinese education system to online learning could be both challenging and interesting.

This paper examines the transformation and challenges faced by university teachers during the COVID-19 pandemic. The study was based on semi-structured online interviews with thirteen university teachers working in Chinese HEIs. The following two research questions guide the study to improve its focus and organization $[20,21]$. (1) What teaching and learning methods were adopted by Chinese university teachers during the COVID-19 pandemic? (2) What are the benefits and challenges encountered in the process? The study provides a robust explanation of the teaching and learning process during the COVID-19 pandemic in China. It also contributes to strengthening the literature on the impact of the COVID-19 on education.

\section{Teaching and Learning during the COVID-19}

As indicated above, HEIs have transformed their teaching and learning process to 'online teaching and learning', which is usually considered one method of distance learning that takes place over the Internet [22]. When COVID-19 forced people to remain indoors, online learning played a significant role in helping students continue their studies using virtual classes, which allowed them to attend classes from anywhere in the world. Research by Jena (2020) in India suggested that online class could be as effective as face-to-face ones if it is used with all necessary tools; moreover, online learning is essential to alleviate mental stress that could arise due to the COVID-19 lockdown or boredom [23]. Other authors have also highlighted that sitting idle for a longer duration can affect people's health and well-being. For example, it can lead to depression and anxiety [24].

However, Pokhrel and Chhetri (2021, p. 134) indicated that online teaching and learning has various limitations: "the weakness of online teaching infrastructure, the limited exposure of teachers to online teaching, the information gap, non-conducive environment for learning at home, equity and academic excellence in terms of higher education". The authors further suggested a need for different pedagogical approaches that fit the courses taught. Although the research literature in this field is in progress, various authors have indicated that online learning has certain limitations and strengths compared to face-to-face learning $[5,25]$. Moreover, the challenges to online learning are pertinent both across and within countries. As Schleicher (2020) stated, students from privileged countries and backgrounds tend to have the resources to help them find their way past closed school doors to alternative learning opportunities. They can continue their learning during COVID-19 through the Internet, television, or radio [1,2]. Nevertheless, those from poor countries 
and backgrounds have no option but to wait for their schools to open after the COVID-19 lockdown is lifted. The COVID-19 lockdown has also depleted the scarce resources of students from disadvantaged backgrounds, as they have not been able to travel to the library and other public spaces where they could get a fast Internet connection and a space to study. This highlights the pandemic's role in exposing and, perhaps, widening the gap between the privileged and the disadvantaged students and, thus, societies.

When countries went to lockdown to contain the spread of COVID-19, higher education institutions (HEIs) were the first to replace their face-to-face classes with online learning [5]. They started transforming their learning environment so that "digitalization expands and complements student-teacher and other relationships" [1] (p. 4). However, as indicated above, such pedagogical transformation is not easy for teachers who have been practicing traditional teaching methods. Therefore, they need proper training to improve their pedagogical knowledge and ICT skills and competencies [26,27]. This could help them manage online learning effectively and, thus, address students' learning needs using student-centered pedagogy. It is, therefore, logical to ask: how is the education system in China, a country with deep-rooted traditional learning methods, coping with the outbreak of COVID-19? The sudden and contagious nature of COVID-19, which gave less time for preparation and planning, also makes the question more interesting.

There are several research projects conducted worldwide regarding online teaching and learning, particularly after the outbreak of the COVID-19 pandemic [6,8,26,28-36]. However, most of these research papers are based on quantitative studies, particularly on survey of students. Moreover, the few studies that focus on teachers' experiences do not concentrate on the pedagogical transformation of the Chinese HEIs and its short and long-term implications [4,6,8,37]. On the other hand, Zhang et al. (2020) indicate that teachers shoulder the largest burden in solving the challenges posed by COVID-19 for the education system as they get little guidance and support from their institutions [6]. This calls for additional and, perhaps, longitudinal studies based on teachers' experiences to extend the available knowledge, which this study partly addresses [38].

Furthermore, regardless of the COVID-19 issue, research has shown that traditional instructional approaches are ineffective in responding to students' learning needs and life situations (Tsegay 2015; Tsegay et al., 2018; Weimer 2003). They fail to promote active engagement of students in the teaching and learning process [17-19]. The disconnection between instructional approaches and learning needs influences the students' social and intellectual development to function in the modern world [39]. Hence, teachers need to shift to interactive teaching methods to help students advance their thinking ability and increase their interest in education [7,37]. Considering the traditional learning methods used in China, we argue that introducing online learning due to COVID-19 could be a 'blessing in disguise' for the country's higher education system. Below we explain the methodology and methods used for this study.

\section{Methodology}

The research focused on the experiences of Chinese higher education teachers regarding the teaching and learning methods during the COVID-19 pandemic. It used qualitative research design as this helps to explore the contextual conditions and realize the phenomena in a broader sense, in order to enable understanding and critical analysis [40]. In addition, the researchers employed a phenomenological approach to help them describe and interpret the lived experiences of the participants from their point of view [41]. Hunan University granted ethical approval to conduct the study. The following sections describe the sample and sampling procedures, and methods of data collection and analysis.

\subsection{Sample and Sampling Procedures}

The target population of this phenomenological study were Chinese university teachers, particularly those who were teaching during the COVID-19 pandemic. We sent an email to potential participants with information about the study and their consent to 
participate in the research. Thirteen (seven male and six female) teachers were selected from a single Chinese university to collect data for the study. The sample teachers were selected using purposive sampling, a non-probability sampling technique that focuses on particular characteristics of a population of interest to the researchers to answer the research questions [21,42]. It is based on the study's objectives and the researchers' knowledge of the population under investigation [43]. Accordingly, purposive sampling was applied to identify and select potential participants representing a broader group of cases for the study [20,42]. Participants who had a minimum of one year of teaching experience and taught during the COVID-19 pandemic were selected for interviews. In addition, we considered other features such as gender and academic discipline to ensure the maximum diversity concerning these criteria. As indicated in Table 1, the participants of this study were from various fields and with different years of teaching experience.

Table 1. Participants' profiles.

\begin{tabular}{cccc}
\hline Pseudonym & Gender & Discipline & Teaching Experience (Years) \\
\hline Janet & F & Business management & 3 \\
\hline Liu & F & Education & 18 \\
\hline Lo & F & Philosophy & 5 \\
\hline Quan & F & Education & 1 \\
\hline Xu & F & Education & 10 \\
\hline Zhang & F & Design & 12 \\
\hline Hu & M & Education & 16 \\
\hline Li & M & Philosophy & 3 \\
\hline Mike & $M$ & Design & 19 \\
\hline Yang & $M$ & Education & 19 \\
\hline Yu & $M$ & History & 24 \\
\hline Yuan & $M$ & Education & 2 \\
\hline Zhu & $M$ & Education & 5 \\
\hline
\end{tabular}

\subsection{Methods of Data Collection and Analysis}

This study is based on qualitative data collected through semi-structured interviews to investigate the experiences of the university teachers. We used semi-structured interviews to obtain adequate information by making the questions flexible and asking additional questions based on the response of the interviewees [44]. The interviews were conducted online using Zoom video communications, which provide significant opportunities for conducting qualitative research [45]. We asked questions regarding the teaching and learning methods used during the COVID-19 pandemic, students' engagement, and the benefits and challenges encountered in the process to address the case under study. We prepared an interview protocol containing the purpose of the study, instructions and interview questions to ensure voluntary participation. Through the interview protocol and a consent form, the participants were informed that participation in the study was voluntary and the participants' responses were confidential [46]. Pseudonyms were used to protect the identity and safety of the participants throughout the research. The interviews were recorded upon the permission of the interviewees. The interviews were conducted in Chinese to allow better communication and expression of ideas and, then, translated to English by one of the researchers (fluent in Chinese and English).

This study employed qualitative data analysis to summarize the key features and offer rich interpretation of the data collected through semi-structured interviews [44,47]. In particular, the study used thematic analysis to systematically categorize and analyze the data and, thus, explore the transcription in different angles for more reliable research findings $[43,48]$. In doing so, using a hybrid of inductive and deductive coding approaches, 
the data were first broken into relatively small units $[20,47]$. Then, a structural skeleton was established through descriptive and explanatory methods to provide for meaningful interpretation and discussion. Finally, the data were interpreted in relation to the literature review to respond to the research questions.

\section{Findings and Discussion}

\subsection{Shifting to Online Teaching}

Before the outbreak of COVID-19, most Chinese HEIS were engaged in blended learning, whereas others were still using traditional teaching methods. However, the spread of COVID-19 forced many educational institutions to either suspend their academic activities or shift to online teaching [1]. After a short suspension period, Chinese HEIs transformed their academic activities into online learning [4]. Similarly, the case university changed its teaching and learning activities to online, which was the first experience of teaching online for most of the teachers. Regarding this, Zhu said:

Interviewer: Did you teach online classes before the outbreak of COVID-19?

Zhu: No.

Interviewer: What did you feel the first time you were told to teach online?

Zhu: I was very worried. Like many of our colleagues, I had never taught online before. Therefore, I was worried that I would not find relevant resources for my class. I was also concerned that I would not be able to handle the technology. Besides, many things were not clear. For example, I was told to make a good connection with students. It was scary. Then I started to prepare several days in advance.

Interviewer: How did it go?

Zhu: Ah.. in the first time, I had very low confidence. I didn't master the technology at that time. But I slowly became familiar with the situation and slowly started developing my capacity and class management.

The concern about teaching online classes was not exclusive to Zhu, but was a common phenomenon among all of the participants of this study. They were not confident about their skills in using the ICTs and pedagogies required to teach online classes. For example, Yang stated:

My first reaction was very 'confusing'. I was not sure about how to do it. I was not sure whether I could teach well online and whether online teaching has any good effect on students' learning. I started teaching my classes with these doubts.

This suggests that the teachers were worried that they might not manage to teach online or engage their students properly. Some participants, such as Zhu and Yang, were even unsure whether the online classes would work and they would be good enough to give students adequate knowledge. This study highlighted teachers' concerns, their perception of online learning, and the lack of training on online teaching. Previous studies have revealed that lack of teachers' technological knowledge poses a significant challenge to the implementation of online learning [6]. However, this study further indicates that lack of technological knowledge and experience could cause anxiety, doubt, and lack of confidence.

The data also showed that many participants of this study were not keen on online learning. They expressed concerns that online learning was "not organic" and "lacks emotional interaction". For example, Li reflected:

There is emotional interaction in face-to-face teaching. However, online learning, has limited emotional interaction because it is difficult to follow all the students' physical and emotional reactions. In addition, many students turn off their videos which blocks visual communication. These challenges limit the teacherstudent relationships. 
In most cases, these explanations are based on their experiences with traditional or blended teachings, where teachers can meet their students and see their development physically, rather than virtually, as in the case of online learning. As Ashraf et al. (2021) indicated, these limitations of online learning affect teachers' perceptions of the teaching approach and their motivation to use them. Moreover, the teachers expressed concern that online learning is inferior to face-to-face learning or blended learning. Partly, this was explained in terms of their capacity, and many of the teachers felt that they were not skilled enough to teach online. Explaining this, Zhu and Liu stated:

I often think about the effect of online teaching, and I think it is not as effective as offline one. This is mainly related to the teacher's confidence, skill, interaction (with students) and the resources. Students can open their computers (online platforms) and might decide to do other things by turning off their videos. It is difficult to get hold of them as in offline classes. So, in this case, I think the quality is inferior. It is not as effective as offline. ( $\mathrm{Zhu}$ )

I did not want to teach online. This perception was related to my lack of understanding of online teaching itself. I am also not good at handling IT and similar equipment. On the other hand, I also feel that online teaching is not effective. In the beginning, I was psychologically against this type of teaching. (Liu)

All of our participants echoed Zhu's statement. Despite its flexibility and the fact that online teaching was introduced for safety during the pandemic, the data highlighted many challenges teachers and students face. Our findings indicated that teaching online classes from a small screen (mostly computers) appeared to limit the teachers' interaction with their students. Other research indicates that limited social interaction is a disadvantage of online education [4].

Furthermore, as Liu noted above, the participants of this study indicated that they did not get adequate training concerning online teaching and learning. Many participants of this study noted that this was not a surprise because most Chinese HEIs had little experience in online learning. However, the sudden outbreak of the COVID-19 pandemic pushed educational institutions to start working online. The participants further expressed that the lack of (in-service) training was one of the factors that affected their experiences while transforming to online learning due to the COVID-19. For example, Hu said:

I got no training regarding online learning. When I was asked to do online classes, I was confused. I sent messages and asked what kind of classroom the university was talking about. Does this mean using Tencent conference, or what else? I had some knowledge of Tencent conferences and some of the online courses (Massive Open Online Courses-MOOCs) offered by American universities. However, I thought it was not easy for me to use it. Some basic knowledge would not be enough without adequate training on using them. Well, I was not familiar with how to use them.

Many of the participants highlighted their lack of knowledge and training in online teaching and learning and its delivery methodologies. These challenge appeared to affect the teachers' perceptions of their competence and confidence to deliver quality online classes. Moreover, they influence the students' participation and interest in the teaching and learning process [18,19]. This suggests that the initial transition stage from offline or blended learning to online learning was not smooth and interactive. Nonetheless, the participants of this study noted that they gradually started to gain experience and transform the teaching and learning process to become more interactive and student-centered.

\subsection{Adopting Student-Centered Teaching}

The participants of this study explained that they gradually gained more knowledge and experience about online learning, and adopted student-centered teaching. In fact, many argued that one of the strengths of online learning is helping students become independent learners. Nevertheless, this requires the motivation, direction, and inclusion of students 
in the teaching and learning process to research, collaborate, and become co-producers of their knowledge. For instance, Zhu stated that he was impressed at the engagement and feedback of students when he allowed them to participate in the lesson design.

Before starting the lesson, I discussed the lesson design with my students, and I found that interesting especially to the students. Their participation was very high. I was surprised to hear that the students reported the situation to my department. I was praised for engaging the students during my lesson design. I was called to the department and informed that my students were pleased with my classes. I did not expect such an outcome from the online class that I was worried about. I was impressed. (Zhu)

Yang also came up with another approach to enable students to become part of the teaching and learning process.

I simplify my lectures to help students quickly get the objectives of my lessons and engage in my class. I divide the contents of my lectures into several parts and use interactive pedagogies in most of them. Such design often motivates students' involvement in class. (Yang)

Zhu's and Yang's excerpts indicate that online learning could be interactive when teachers have relevant knowledge and skills and are keen to involve students. This finding argues that online learning could be as effective as face-to-face learning [45]. However, students need to be given an opportunity in the lesson design and delivery in order to engage actively in the teaching and learning process. This further suggests that studentcentered approach should not only center on student needs and interests $[18,19]$, but it should also emanate from the students.

The findings of this study indicate that teachers need to create a conducive environment and use appropriate teaching methods and materials to ensure student-centered teaching and learning. The participants explained that they often take a long time to prepare for online teaching, particularly to create an environment where students can freely interact. In this instance, $\mathrm{Li}$ and Mike said:

I spend a lot of time and energy to ensure a suitable class atmosphere to mobilize students to be part of the teaching and learning process. I also try to design my lectures in a way that motivates students' participation. For example, I use posing questions to students to stimulate students' interaction and frame their attention to the lesson. I faced some challenges regarding my lack of skills in teaching online classes, especially in the first few lessons. Exploring various online classes, such as MOOCs and Harvard open classes, was helpful to get relevant teaching resources and understand how online classes should be run. ( $\mathrm{Li}$ )

There are many online courses, including MOOCs, that are essential to developing our capacity. I also use them in classes. I watch some good video clips to get a general knowledge about online teaching and relevant to my subject area. These courses/resources are good, but I don't think they have been adequately utilized in colleges and universities. (Mike)

As indicated above, Li's quotation postulates that teachers play a significant role in creating a suitable environment for student learning and the direction and motivation of students. The findings indicate that teachers used different methods to gain their students' attention and interaction in class. Moreover, Li disclosed capacity-related challenges that teachers face and the strategies they use to ease these challenges, especially where there was a lack of in-service teacher training and relevant resources. Mike, Janet, Zhu, Liu, Yu, and many other participants of this study concur with Li that there are many online courses being taught in other universities that could serve as an example. These courses could help teachers explore various examples of online teaching and online teaching resources to develop their capacity and run their classes smoothly. This suggests that teachers can use other strategies and resources to enhance their professional skills if there is a lack 
of institutional support for online teaching. For example, Janet highlighted that online resources could be used to support students to be part of the class discussion.

Most of the participants of this study noted that they gradually learned how to run online classes and adopt student-centered teaching. Nonetheless, in most cases, the first online module or course that teachers teach and the first few sessions of the module, in particular, were negatively affected. $\mathrm{Li}$, for example, noted that he used the first week of his course to test his lesson plans and teaching approaches and get feedback from students for improvement.

I started my class [module] in the second week. Along with the students, I understood from the first week that some problems will certainly exist. So, I get prepared for such problems, rather than just being worried about what will happen. (Li)

I used the first two classes to set my teaching practice. I got feedback from students. They mostly gave me feedback regarding their feelings about the whole course, which was helpful. I also used their class interaction. assignments, teaching resources, and students' disruptions to understand how the online class is being handled. ( $\mathrm{Zhu}$ )

This reflective learning appeared to be common to the majority of the participants, as they tested their teaching approaches and materials for their classes in the first weeks and adapted them. As Zhu stated, the teachers learned from the students' desire to learn and the level of the class interaction. The teacher participants also assessed if there were any additional barriers to learning, such as students' disruptions, or outside noise, and availability and clarity of PPTs, videos, and other teaching aids. These factors affect the teaching and learning process and student-centered teaching, in particular. This finding concurs with earlier research that highlights the significance of the environment and teaching aids in promoting student-centered teaching [49].

\subsection{Benefits and Challenges}

Most of the participants of this study expressed concerns about their experiences of online teaching and learning in general, and during the COVID-19 pandemic, in particular, with reference to their prior experiences of face-to-face or blended learning. Although they generally preferred face-to-face teaching to online teaching, the participants also indicated that online learning has some benefits. The following discusses the benefits and challenges of online learning from the participants' perspectives.

\subsubsection{Benefits}

As suggested by the quotes above, many of the teachers who participated in this study indicated that they did not initially have a positive perception of online learning and believed it would be difficult to adopt online learning considering their ICT and pedagogical knowledge. However, the social and structural changes that occurred to education during the pandemic did not leave them with any choice but to transform their teaching approach to online learning. Despite its many challenges, the participants acknowledged that online learning offered the teachers and students advantages related to time, resources, and lifelong learning.

The fact that online learning allows students to learn from home offered both the students and teachers some flexibility, and it saved them some time as they were no longer travelling to classes. Li and Mike described some of their experiences:

There is the limitation of time and space with offline (face-to-face) classes. Online classes avoid such restrictions and help teachers and students to teach/learn from home. The time saved can be used for other purposes such as class preparation. Online learning also helps poor universities as it saves resources. (Li)

Teaching online does not require going to universities to take classes. I sit in my home and connect to my class through the internet. I believe this is what the future 
university will look like, maybe after 10 or 20 years. This costs less to students and universities as there are no expenses for transportation, space/classroom, electricity, air conditioner and other services. (Mike)

From Li's and Mike's perspective, using remote teaching can help teachers and students teach, or learn, from any part of the world as long as they have a computer and good internet connection. This saves time and money spent on going and preparing classrooms, respectively. It also removes the limitation of space, particularly classrooms, for teaching. Zhu further added that, in a time of the COVID-19 pandemic, online learning minimized the risk of catching the virus and, thus, helped both teachers and students to focus on education. As Lo Moro et al. (2020) suggest students and teachers need to wear a mask and ensure social distancing in face-to-face learning [50]. However, this may not stop them from worrying about getting the virus in class, and this may mean that it would be difficult for staff and students to focus on the teaching-learning process.

Furthermore, the findings from this study indicate that one of the significant effects of COVID-19 on teaching and learning was the rapid transformation of the Chinese higher education system and the teaching approaches, in particular, from traditional to digital and, most importantly, to develop new interactive teaching methods. All of the participants also emphasized that the implementation of online learning was a step forward to the development of education in China. It is with this notion that Li stated:

Online learning is changing the long tradition of teaching and learning in Chinese classes. In fact, using traditional or face-to-face teaching approaches were common and teachers were resistant to change. Using online learning due to COVID-19 is an important step in changing the long-established teaching approaches and using the available ICTs.

As can be seen, the teacher participants argued that the adoption of online learning due to the outbreak of COVID-19 could have a long-term impact on the Chinese education system. The majority of classes might return to face-to-face learning after the eradication of COVID-19. However, all participants of this study noted that they would not turn back to the traditional "teacher-dominated" teaching approach. Moreover, the findings indicated that the teachers have learnt to extend their pedagogical practice by using different teaching approaches and integrating ICTs in their classes. They suggested that teaching could become more lively and enjoyable when students become active learners and engage in cooperative and co-productive learning, rather than simply sitting and copying whatever is given to them. This is what most critical educators and Freire (2010) and Hooks (2010), in particular, have been arguing for decades. Overall, the findings from this study indicated that the adoption of online learning could change Chinese academia towards blended learning and student-centered approaches to teaching and learning.

\subsubsection{Challenges}

The outbreak of the COVID-19 pandemic forced countries to either suspend the teaching and learning process or transform it to online learning. As a result, most Chinese HEIs transformed their teaching to online learning. Although the adoption of online learning has some short and long-term benefits, this change was not without limitations. Many of the challenges or constraints identified by the participants were related to lack of uninterrupted electricity/internet, teachers' ICT skills, and physical/emotional interaction. For example, Zhang stated:

Not all students have uninterrupted electricity and a strong internet connection. There are cases where students choose to switch to mobile data, but that is not convenient to simultaneously turn on their videos, follow the slides and interact. Well. in face-to-face teaching and learning, we did not have such concerns.

Zhang's argument corroborates other studies that indicate the impact of socio-economic inequalities on online learning [1]. Although the development and integration of ICT into 
education has shown significant progress in China [3], the quality and quantity of education remain different between urban and rural areas, and within different provinces and municipalities [12,51]. Moreover, Chinese students have different socio-economic status $[52,53]$. Therefore, it is not surprising that some students lack relevant ICTs while others enjoy them to the fullest. These challenges affect the teaching and learning process. As Zhang et al. (2020) noted, teachers shoulder additional burdens to solve the challenges faced by distributing their teaching materials and other relevant resources [6].

This study also indicates that online learning limited the students' collaborative learning, outdoor learning, and praxis. As shown below, this is partly associated with the online educational setting, management of group discussions, and/or lack of physical and emotional interaction.

The number of undergraduate students is not small. I want to organize class discussions, but it's very troublesome. When everyone starts talking at the Tencent conference, it becomes noisy and challenging to manage. Once the number of people is large, there is confusion. Things also become worse when the students are new [i.e., students that the teacher has not taught them before] because I do not know who is talking. (Zhang)

Online learning is not the best method in capturing students' non-verbal communication. In addition, many students do not open their videos, which makes it difficult to see students' body language. By looking at students' eyes, I can know whether they have got my ideas or are confused. This is mostly impossible or limited in online learning. There is lack of emotional interaction. ( $\mathrm{Hu})$

Most of the participants argued that lack of physical and emotional interaction in online learning could lead to boredom for students and teachers. Moreover, as Zhu noted above, when the students have their camera turned off, the teachers might not know that their students are not happy or if they are not concentrating and doing other things. The teachers further highlighted that lack of physical and emotional interaction could lead to limited class participation, weak student-teacher relationships, low learning interest, and, finally, ineffective learning or acquisition of knowledge. As Zhang stated above, this also connects to the class size considering the time the teacher can devote to class interaction. Research has indicated that large class size is one of the challenges for students' class interaction because the teacher could not get enough time to recognize all the students at a time $[15,17]$.

The majority of the participants also explained that lack of ICT skills and online teaching experiences are other challenges that hinder quality online teaching and learning. $\mathrm{Li}$ and $\mathrm{Hu}$ stated:

In the beginning, I was taking more time to prepare a video recording. I used to finish one video after many trials. I had to start again if something went wrong. This took me a long time as I had no special training to do such things. I think computer training or assistance [from specialists] would be a great help. ( $\mathrm{Li}$ )

I am not familiar with computer systems and software. I have not received any training. However, I have an advantage at home. My son-in-law specializes in computers, and my daughter is a web designer. Both of them are familiar with computer applications. ( $\mathrm{Hu})$

Li's and Hu's points indicate that while the university had no history of online learning, the institution and the teachers changed to new teaching practices without making necessary preparations due to the COVID-19 pandemic. This required that teachers learn how to use ICTs independently and seek help from others. Moreover, as shown above, this study indicates that teachers felt that they lack pedagogical skills and knowledge and a positive perception towards digital learning. All these situations make teachers shoulder multiple responsibilities, primarily to fully accept online learning and prepare for it in terms of ICTs and pedagogy $[6,35]$. This suggests that online teaching and learning 
require good planning and communication strategies that allow teachers and students to work collaboratively.

\section{Conclusions}

Like many other HEIs globally, Chinese universities adopted online learning during the COVID-19 outbreak. Considering the deep-rooted traditional face-to-face teaching methods in China, the teachers who participated in this study found it challenging to transform to online learning. Moreover, the sudden and contagious nature of the COVID19 pandemic did not give HEIs ample time to offer ICT and pedagogical training to their teachers. Most teachers used the little knowledge they had to learn how to create videos and manage online classes independently. In contrast, others depended on external support, such as family support. This study also revealed that, at first, many of the teachers had a negative perception towards online learning, which affected teachers' and students' confidence and motivation $[7,54,55]$. However, they gradually recognized the benefits that online teaching and learning could offer. These findings add relevant insight to the evidence presented by Ashraf et al. (2021) and Jena (2020). Online learning could be more effective if used with relevant teaching approaches and teaching aids.

Despite its challenges, the COVID-19 pandemic could transform the traditional teaching approach to an interactive and, perhaps, student-centered method. The findings of this study indicated that online learning has limitations related to lack of social interaction and field study. Nevertheless, the teaching and learning approach has short and long-term benefits. It helps protect anxiety and depression that could arise due to long-term COVID-19 lockdown and sitting idle. Online learning could also transform the deep-rooted traditional teaching approach in China. Teachers are expected to strengthen using student-centered approach and integrating ICT in their classrooms after the eradication of COVID-19. In this case, the study concurs with Zhang et al., (2020) that teachers shoulder the most considerable responsibilities in implementing online learning and solving any challenges faced [6].

This study has investigated the adoption of online teaching in Chinese HEIs during the COVID-19 outbreak. However, it is confined to a limited number of participants from a sample university. Therefore, similar studies regarding the adoption of online learning by academic disciplines or fields of study are required to strengthen the findings and broaden people's understanding of the case.

Author Contributions: Conceptualization, S.M.T. and M.A.A.; methodology, S.M.T. and M.A.A.; formal analysis, S.M.T. and M.A.A.; investigation, S.M.T. and M.A.A.; resources, S.M.T., M.A.A., S.P. and M.Z.Z.; writing—original draft preparation, S.M.T. and M.A.A.; writing-review and editing, S.M.T., M.A.A., S.P. and M.Z.Z.; supervision, S.M.T. and M.A.A.; project administration, S.M.T. and M.A.A.; funding acquisition, M.A.A. All authors have read and agreed to the published version of the manuscript.

Funding: This research was supported by National Natural Science Foundation of China under Grant number 71950410624. Opinions reflect those of the authors and do not necessarily reflect those of the grant agencies.

Institutional Review Board Statement: The study was conducted according to the guidelines of the Declaration of Helsinki, and approved by the Ethics Committee of Hunan University (Ethics Code: Experimental Research on Blended Learning).

Informed Consent Statement: Informed consent was obtained from all participants involved in the study.

Data Availability Statement: Not applicable.

Acknowledgments: We thank Pauline Lane and the anonymous reviewers for reading the manuscript and providing constructive feedback, which improved the article.

Conflicts of Interest: The authors declare no conflict of interest. 


\section{References}

1. Schleicher, A. The Impact of COVID-19 on Education Insights from Education at a Glance 2020; OECD: Paris, France, 2020. Available online: https:/ / www.oecd.org/education/the-impact-of-covid-19-on-education-insights-education-at-a-glance-2020.pdf (accessed on 12 August 2021).

2. Di Pietro, G.; Biagi, F.; Costa, P.; Karpiński, Z.; Mazza, J. The Likely Impact of COVID-19 on Education: Reflections Based on the Existing Literature and Recent International Datasets; Publications Office of the European Union: Brussels, Belgium, 2020 ; Volume 30275.

3. Guo, W.; Yang, Z. A Study of Integration ICT into Curriculum in China's Developed Areas-A Case of Foshan City. In Proceedings of the 2016 6th International Conference on Management, Education, Information and Control (MEICI 2016), Shenyang, China, 24-26 September 2016; Atlantis Press: Paris, France, 2016; pp. 594-598.

4. Bao, W. COVID-19 and online teaching in higher education: A case study of Peking University. Hum. Behav. Emerg. Technol. 2020, 2, 113-115. [CrossRef]

5. Pokhrel, S.; Chhetri, R. A literature review on impact of COVID-19 pandemic on teaching and learning. High. Educ. Future 2021, 8, 133-141. [CrossRef]

6. Zhang, W.; Wang, Y.; Yang, L.; Wang, C. Suspending Classes without Stopping Learning: China's Education Emergency Management Policy in the COVID-19 Outbreak. J. Risk Financ. Manag. 2020, 13, 55. [CrossRef]

7. Ashraf, M.A.; Tsegay, S.M.; Yang, M. Blended learning for diverse classrooms: Qualitative experimental study with in-service teachers. Sage Open 2021, 11, 21582440211030623. [CrossRef]

8. Li, S.; Zheng, J.; Zheng, Y. Towards a new approach to managing teacher online learning: Learning communities as activity systems. Soc. Sci. J. 2021, 58, 383-395. [CrossRef]

9. Tsegay, S.M. Students' experience in student-centered learning at higher education institutions in China: A case study. EDUCARE Int. J. Educ. Stud. 2015, 7, 135-146.

10. Garrison, D.R.; Vaughan, N.D. Blended Learning in Higher Education: Framework, Principles, and Guidelines; John Wiley \& Sons: Hoboken, NJ, USA, 2008.

11. Ertmer, P.A. Teacher pedagogical beliefs: The final frontier in our quest for technology integration? Educ. Technol. Res. Dev. 2005, 53, 25-39. [CrossRef]

12. Ashraf, M.A.; Shuiyun, L.; Ismat, H.I.; Tsegay, S.M. Choice of higher education institutions: Perspectives of students from different provinces in China. Front. Educ. China 2017, 12, 414-435. [CrossRef]

13. Dello-Iacovo, B. Curriculum reform and 'Quality Education' in China: An overview. Int. J. Educ. Dev. 2009, 29, 241-249. [CrossRef]

14. Guo, L.; Huang, J.; Zhang, Y. Education development in China: Education return, quality, and equity. Sustainability 2019, 11, 3750. [CrossRef]

15. Tsegay, S.M. The role of higher education in nurturing global citizenship in Eritrea. Span. J. Comp. Educ. 2016, $28,183-201$.

16. Tsegay, S.M.; Ashraf, M.A. The influence of senior secondary school teachers on students' achievement in Gao-Kao. Int. J. Res. Stud. Educ. 2015, 4, 67-76. [CrossRef]

17. Tsegay, S.M.; Zegergish, M.Z.; Ashraf, M.A. Pedagogical practices and students' experiences in Eritrean higher education institutions. High. Educ. Future 2018, 5, 89-103. [CrossRef]

18. Freire, P. Pedagogy of the Oppressed; The Continuum International Publishing Group Inc.: New York, NY, USA, 2010.

19. Hooks, B. Teaching Critical Thinking: Practical Wisdom; Routledge: New York, NY, USA; London, UK, 2010.

20. Creswell, J.W. Qualitative Inquiry \& Research Design: Choosing among Five Approaches; SAGE Publications, Inc.: Los Angeles, CA, USA, 2013

21. Silverman, D. Doing Qualitative Research, 4th ed.; SAGE Publications, Inc.: Los Angeles, CA, USA, 2013.

22. Sarkar, L. Online Language Teaching and Learning: Present Condition and Future Prospects in Bangladeshi Primary Education System. Ph.D. Thesis, BRAC University, Dhaka, Bangladesh, 2016.

23. Jena, P.K. Online learning during lockdown period for covid-19 in India. Int. J. Multidiscip. Educ. Res. IJMER 2020, 9, 82-92.

24. Budd, J.W.; Spencer, D.A. Worker well-being and the importance of work: Bridging the gap. Eur. J. Ind. Relat. 2015, 21, 181-196. [CrossRef]

25. Castro, R. Blended learning in higher education: Trends and capabilities. Educ. Inf. Technol. 2019, 24, 2523-2546. [CrossRef]

26. Baranova, S.; Nìmante, D.; Kalnina, D.; Olesika, A. Students' Perspective on Remote On-Line Teaching and Learning at the University of Latvia in the First and Second COVID-19 Period. Sustainability 2021, 13, 11890. [CrossRef]

27. Jingtao, Z.; Yuanyuan, F.; Xiaoling, M. The latest progress report on ICT application in Chinese basic education. Br. J. Educ. Technol. 2010, 41, 567-573. [CrossRef]

28. Alismaiel, O.A. Using Structural Equation Modeling to Assess Online Learning Systems' Educational Sustainability for University Students. Sustainability 2021, 13, 13565. [CrossRef]

29. Han, J.; Geng, X.; Wang, Q. Sustainable Development of University EFL Learners' Engagement, Satisfaction, and Self-Efficacy in Online Learning Environments: Chinese Experiences. Sustainability 2021, 13, 11655. [CrossRef]

30. Hermanto, Y.B.; Srimulyani, V.A. The challenges of online learning during the covid-19 pandemic. J. Pendidik. Dan Pengajaran 2021, 54, 46-57. [CrossRef]

31. Hettiarachchi, S.; Damayanthi, B.; Heenkenda, S.; Dissanayake, D.; Ranagalage, M.; Ananda, L. Student Satisfaction with Online Learning during the COVID-19 Pandemic: A Study at State Universities in Sri Lanka. Sustainability 2021, 13, 11749. [CrossRef] 
32. Jiménez-Bucarey, C.; Acevedo-Duque, Á.; Müller-Pérez, S.; Aguilar-Gallardo, L.; Mora-Moscoso, M.; Vargas, E.C. Student's Satisfaction of the Quality of Online Learning in Higher Education: An Empirical Study. Sustainability 2021, 13, 11960. [CrossRef]

33. Martín-Hernández, P.; Gil-Lacruz, M.; Gil-Lacruz, A.I.; Azkue-Beteta, J.L.; Lira, E.M.; Cantarero, L. Fostering University Students' Engagement in Teamwork and Innovation Behaviors through Game-Based Learning (GBL). Sustainability 2021, $13,13573$. [CrossRef]

34. Omar, H.A.; Ali, E.M.; Belbase, S. Graduate Students' Experience and Academic Achievements with Online Learning during COVID-19 Pandemic. Sustainability 2021, 13, 13055. [CrossRef]

35. Suryaman, M.; Cahyono, Y.; Muliansyah, D.; Bustani, O.; Suryani, P.; Fahlevi, M.; Munthe, A.P. COVID-19 pandemic and home online learning system: Does it affect the quality of pharmacy school learning. Syst. Rev. Pharm. 2020, 11, 524-530.

36. Wang, C.; Wang, W.; Wu, H. Association between medical students' prior experiences and perceptions of formal online education developed in response to COVID-19: A cross-sectional study in China. BMJ Open 2020, 10, e041886. [CrossRef] [PubMed]

37. Chiu, T.K.; Lin, T.J.; Lonka, K. Motivating online learning: The challenges of COVID-19 and beyond. Asia-Pac. Educ. Res. 2021, 30, 187-190. [CrossRef]

38. Zhu, X.; Liu, J. Education in and after Covid-19: Immediate responses and long-term visions. Postdigital Sci. Educ. 2020, 2, 695-699. [CrossRef]

39. Weimer, M. Focus on learning, transform teaching. Chang. Mag. High. Learn. 2003, 35, 48-54. [CrossRef]

40. McNabb, D.E. Research Methods in Public Administration and Non-profit Management: Quantitative and Qualitative Approaches, 2nd ed.; PHI Learning Private Limited: New Delhi, India, 2008.

41. Cohen, L.; Manion, L.; Morrison, K. Research Methods in Education; Routledge: New York, NY, USA, 2013.

42. Teddlie, C.; Yu, F. Mixed methods sampling: A typology with examples. J. Mix. Methods Res. 2007, 1, 77-100. [CrossRef]

43. Wiersma, W.; Jurs, S.G. Research Methods in Education: An Introduction, 8th ed.; Pearson Education Asia Ltd.: Hong Kong; China Light Industry Press: Beijing, China, 2004.

44. Bryman, A. Social Research Methods; Oxford University Press: New York, NY, USA, 2008.

45. Archibald, M.M.; Ambagtsheer, R.C.; Casey, M.G.; Lawless, M. Using zoom videoconferencing for qualitative data collection: Perceptions and experiences of researchers and participants. Int. J. Qual. Methods 2019, 18, 1609406919874596. [CrossRef]

46. National Commission for the Protection of Human Subjects of Biomedical and Behavioural Research. The Belmont Report: Ethical Principles and Guidelines for the Protection of Human Subjects of Research. 1978. Available online: http://videocast.nih.gov/ pdf/ohrp_appendix_belmont_report_vol_2.pdf (accessed on 15 September 2021).

47. Braun, V.; Clarke, V. Using thematic analysis in psychology. Qual. Res. Psychol. 2006, 3, 77-101. [CrossRef]

48. Sparker, A. Narrative analysis: Exploring the whats and hows of personal stories. In Qualitative Research in Health Care; Holloway, I., Ed.; Open University Press: Berkshire, UK, 2005; pp. 191-208.

49. Young, J. Encouragement in the Classroom: How Do I Help Students Stay Positive and Focused? ASCD Arias; ASCD: Alexandria, VA, USA, 2014.

50. Lo Moro, G.; Sinigaglia, T.; Bert, F.; Savatteri, A.; Gualano, M.R.; Siliquini, R. Reopening schools during the COVID-19 pandemic: Overview and rapid systematic review of guidelines and recommendations on preventive measures and the management of cases. Int. J. Environ. Res. Public Health 2020, 17, 8839. [CrossRef]

51. Tsegay, S.M.; Kansale, C.; Goll, S.P. An analysis of early childhood education policy in China. Asia Pac. J. Res. Early Child. Educ. 2017, 11, 69-84. [CrossRef]

52. Hannum, E.C.; Wang, M. Ethnicity, Socioeconomic Status, and Social Welfare in China; Asia-Pacific Education, Language Minorities and Migration (ELMM) Network Working Paper Series 2. 2010. Available online: http://repository.upenn.edu/elmm/2 (accessed on 20 September 2021).

53. Liu, J.; Peng, P.; Luo, L. The relation between family socioeconomic status and academic achievement in China: A meta-analysis. Educ. Psychol. Rev. 2020, 32, 49-76. [CrossRef]

54. Valcke, M.; Sang, G.; Rots, I.; Hermans, R. Taking prospective teachers' beliefs into account in teacher education. Int. Encycl. Educ. 2010, 7, 622-628.

55. Wang, N.; Chen, J.; Tai, M.; Zhang, J. Blended learning for Chinese university EFL learners: Learning environment and learner perceptions. Comput. Assist. Lang. Learn. 2021, 34, 297-323. [CrossRef] 